\title{
Revealing Youngsters' Impulsive Buying Behavior through Hedonic Shopping Motivations
}

\author{
Ayaz Samo ${ }^{1} \quad$ Fiza Rani $^{2} \quad$ Hamid Shaikh $^{3} \quad$ Maqsood Bhutto $^{2}$ \\ Fayaz $\mathrm{Samo}^{3 *}$ Tahseen Bhutto ${ }^{3}$ \\ 1.School of Business Administration, Shah Abdul Latif University, Khairpur, Sindh, Pakistan \\ 2.Sukkur Institute of Business Administration, Sindh, Pakistan \\ 3.School of Business Administration, Dongbei University of Finance and Economics, Dalian, China
}

\begin{abstract}
This paper evaluates the relationship between hedonic shopping motivations and impulsive buying behavior of young Chinese buyers. 615 respondents are surveyed using convenience sampling and analyzed through Structural Equation Modelling. The results indicate that adventure seeking, gratification seeking, and idea shopping have a positive effect on impulsive buying, whereas role shopping has a negative effect on impulsive buying. However, social shopping and value shopping are found to be insignificant to impulsive buying. The study contributes to impulsive buying by investigating the hedonic shopping motivations of young Chinese buyers which is so far found to be missing in the existing literature.
\end{abstract}

Keywords: Hedonic shopping; impulsive buying; young consumers; China.

DOI: $10.7176 / \mathrm{EJBM} / 11-3-13$

\section{Introduction}

Recent studies have found that Chinese consumers love to spend money on shopping, and nearly spend about 30 minutes a day on China's leading online shopping app Taobao according to China's National Bureau of Statistics (Chris Biggs, 2017). The new generation of Chinese consumers grows up in a better environment with improving economic conditions. They have potential to spend money on recreational activities including sports, traveling, gaming, and dining out as their family income tends to rise. This consumer segment unlocks the door for potential growth opportunities for marketers to capitalize in the field of hedonic shopping motivations (Ngai and Cho, 2012). Moreover, the study on hedonic shopping motivations of young consumers from the perspective of impulsive shopping is so far lacking in the literature to the best of authors' knowledge. Thus, exploring the phenomenon of the underlying hedonic motivations of young Chinese consumers to buy impulsively is a novel contribution to the literature.

Hedonic shopping experiences that customers want are virtually endless in nature (Arnold and Reynolds, 2003). Researchers have long recognized the potential value of hedonic shopping motivations (Babin et al., 1994). Hedonic values and consumption habits are attributed to the behavior that receives multisensory, emotive, and fantasy factors of buying and consumption (Hirschman and Holbrook, 1982). It is found that some consumers, especially women regard shopping as an expression of love (Otnes and McGrath, 2001). Hedonic shopping is described as values of acquiring excitement and joy while engaging in shopping products and services (Batra and Ahtola, 1991). It is further studied that modern shopping environment (Anderson et al., 2014) with respect to emotions, moods, and fantasies is the key driving feature of pleasure shopping (Rayburn and Voss, 2013). Therefore, studying the hedonic aspects of young Chinese consumers in relation to impulsive buying is a valuable contribution to understand the underlying shopping behavior of this consumer segment.

\section{Literature Review and Hypotheses Development}

\subsection{Hedonic Motivations and Impulsive Buying Behavior}

Hedonic motivations are known to be the feelings and emotions attached to and derived from impulsive shopping (Baumeister, 2002). It is found in the previous studies that impulsive buying is relevant to individual's hedonic motivations (Rook and Hoch, 1985, Tifferet and Herstein, 2012). The dimensions of hedonic motivations are more associated with personal and subjective factors of an individual such as fun, playfulness, and emotions derived from impulsive buying (Babin et al., 1994). Hedonic motives drive a person to shop for pleasure (Gültekin and Özer, 2012). Earlier researchers have also studied that hedonic shopping motivations may produce impulsive buying behavior (Babin et al., 1994). Herabadi et al. (2010) describe the temperaments of impulsive buyers as to get satiated when their impulsive buying behavior acts an arousal regulation mechanism. Impulsive buying behavior stimulates quicker decision making and prompt possession (Rook and Gardner, 1993). Impulsive purchase behavior is different from planned buying behavior with respect to temptation, stimulation, and deliberation involved in buying decisions (Kacen and Lee, 2002). The researches on impulsive buying behavior have noticeably been shifted across product categorization and locations suited for impulsive shopping (Yu and Bastin, 2010). Various studies have been done to study the psychological factors of impulsive buying behavior (Verplanken and Herabadi, 2001, Luo, 2005, Dawson and Kim, 2009, Harmancioglu et al., 2009, 
Sharma et al., 2010). The purpose of carrying out this research is to help enrich the impulse purchase literature from youngster's shopping behavior perspective and for those managers who believe China as a key marketplace for their products and services.

\subsection{Dimensions of Hedonic Shopping Motivations}

\section{Adventure Seeking}

Adventure seeking denotes excitement shopping. It describes the shopping motives for pure stimulation, wonder, and adventure. It implies that buyers encounter something different, novel, and interesting. Their curiosity will produce an act of venture (To et al., 2007a). Adventure seeking is found to be one of the motivations for impulsive buyers. It is found that consumers in emerging markets often search for adventure in their shopping environment (Horváth and Adıgüzel, 2017). With this kind of shopping motives, consumers often feel as if they are in another universe. A potential number of impulsive consumers indicated that their purpose of shopping is sheer adventure and excitement. They want to enjoy the feeling of awe and wonder of their shopping trip. Shopping for adventure is deep-rooted in stimulation. Zuckerman (1993) defines that physical, legal, social, and financial risks are linked to impulsive sensation seeking for consumers who seek sensational experiences and hence lead to non-rational behaviors such as gambling and promotional games (McDaniel and Zuckerman, 2003), adventure sports (Jack and Ronan, 1998), and lottery buying (George, 2002). Adventure shopping corresponds to the earlier established findings showing that impulsive buyers usually seek sensory excitement and stimulation during their shopping activity. Hence, we hypothesize that:

H1. Adventure seeking is positively related to impulsive buying.

\section{Gratification Seeking}

Gratification seeking in the shopping activity is described as shopping for stress relief, negative mood alleviation, and special treatment to oneself (Arnold and Reynolds, 2003). Rook and Gardner (1993) studied the mood associations with impulse buying, they defined shopping impulses as an umbrella idiom that holds weak measures of spontaneous and deliberate course of actions. Consumers with high impulse tendencies are more likely to be emotionally engrossed in buying and look to gain immediate gratification irrespective of potential, adverse consequences that may arise from their unplanned shopping behavior (Hoch and Loewenstein, 1991). Impulsive buyers during their shopping activity tend not to worry about the costs and end results related to their sudden buying decisions. Their desire for immediate gratification supersedes all the competing factors of reasoning and rationality. Immediate pleasure is the only choice they want to satisfy themselves with. For this reason, gratification is a source for impulsive buyers to satisfy the short-lived pleasures (Jones et al., 2003, Rook, 1987). Hence, we hypothesize that:

H2. Gratification seeking is positively related to impulsive buying.

\section{Idea Shopping}

Idea shopping refers to keeping oneself up-to-date with the latest trends and fashions. It also includes seeing new products and innovations in the marketplace for collecting information. It is reported that the purpose of a large number of males and females is to see what new products are available in the market, while some respondents claimed that their intention to go shopping is to keep up with new products and innovations (Arnold and Reynolds, 2003). Some consumers shop for utilitarian shopping motivations, such as cost saving, convenience, and selection, while others do so for hedonic shopping motivations such as; adventure, status, and authority. Since impulsive buyers tend not to worry about negative outcomes (Rook, 1987), they are highly susceptible to both internal and external stimuli (Rook and Fisher, 1995). Impulsive buying is likely to increase when consumers are exposed to certain external stimuli (Iyer, 1989). Such stimuli, in the form of ideas, are more likely to instigate the urge to buy products more impulsively than obsessively. Hence, we hypothesize that:

H3. Idea shopping is positively related to impulsive buying.

\section{Role Shopping}

Role shopping is categorized as reflecting the joy that consumers obtain from shopping for their dear ones. That can be finding the gift for family, friends, or close ones. They believe shopping for others is a very vital component of bonding with them, and it gives them a good feel. In the previous studies, some respondents described that they feel happy when they look around to find a valuable gift for their dear ones (Arnold and Reynolds, 2003). In some studies, role shopping was not found to be a motivating factor for hedonic shopping (Falode et al., 2016), while Rook and Fisher (1995) suggest that when impulsive buying is virtuously influenced, it is more likely for impulsive buyers to buy a gift or avail of promotions such as discounts, two-for-one, or etc. on the spur of the shopping moment for a sick friend... and hence bring about positive feelings and normative evaluations to this kind of buyers. Impulsive consumers rank adventure, authority, and status as important hedonic shopping values of buying (To et al., 2007b). Buying for others tends to improve their self-image and status in the eyes of their ones. Hence, we hypothesize that:

H4. Role shopping is positively related to impulsive buying. 


\section{Social Shopping}

Social shopping is described as enjoyment with family and friends while shopping and looking to socialize and bond with others during shopping (Arnold and Reynolds, 2003). Consumers who seek relationships during their shopping were first identified as "personalizing" shoppers (Stone, 1954). Moreover, Tauber (1972) state that consumers have a desire to keep social interaction with others outside their homes, make free talks with the people with the same interests, and consort with the reference groups. Zhang et al. (2016) describe that material desires tend to increase when consumers socially compare themselves to their neighborhood's social and economic status which bring about more frequent impulsive shopping. Zimmerman (2012) showed that social and status concerns are the main causes of impulsive buying. Culture has also been confirmed to contribute to impulsive buying (Lee and Kacen, 2008). In the findings of earlier research studies, consumers in collectivist cultures are found to identify themselves with self-defining values (Evanschitzky et al., 2014) and thus are more likely to engage in impulsive buying to improve their social image. Hence, we hypothesize that:

H5. Social shopping is positively related to impulsive buying.

6. Value Shopping

Value shopping refers to shopping for discounts, sales, and bargains. Consumers in this category have a major focus to buy quality products on discount. They often look to hunt for bargains and negotiate for reducing the price of the products rating higher in quality. They consider shopping as a challenge to conquer or a game to win (Arnold and Reynolds, 2003). Similarly, Kukar-Kinney et al. (2012) believe that impulse buyers are more inclined to receiving transaction value from price promotions as they tend to be more price conscious than other buyers. Furthermore, Kukar-Kinney et al. (2016) find the positive correlation between coupon size and impulse buying while investigating the tendency of compulsive buyers for shopping. Hence, Marketers use marketing cues to lure consumers to make a purchase decision (Youn and Faber, 2000). Impulsive buyers are more likely to fall into prey under promotional campaigns such as discounts (Xu and Huang, 2014) and limited offer periods (Zheng et al., 2013). Additionally, specific stimuli such as bonus packs, volume deals, and price discounts have also been found to ignite impulsive buying (Pettigrew et al., 2015, Xu and Huang, 2014). These shopping values motivate impulsive buyers to buy products impulsively. Hence, we hypothesize that: H6. Value shopping is positively related to impulsive buying.

\section{Research Methodology}

\subsection{Survey Method and Data Collection}

Data were collected from young Chinese buyers in March 2018. 76 percent of the sample is consisting of female respondents and the average age of the total sample is 24 years (see table 1). The notion of choosing more females is that impulsive buying is more commonly found in females than in males (Hou and Elliott, 2016). Examining the young sample is relevant segment because it forms a target market that is getting financially rich and growing in number (Mangleburg et al., 2004). Moreover, they show greater courage to take a risk and adopt new brands and products quickly than other age group buyers (Dayan et al., 2010).

This study is based on non-probability convenience sampling for the target population. We have collected the data mostly from university students. 30 percent of our questionnaires were filled in-person on physical question papers and the remaining 70 percent of the questionnaires were filled online and collected via WeChat, a social media channel. Since the target population of our study is well defined, we used 'WeChat' the most widespread and influential social media application in China to collect the data (Gan, 2017).

Structural equation modeling (SEM) is used for the data analysis following the previous studies ( $\mathrm{Li}$ et al., 2018), which investigated the relationship between online and offline shopping behavior (Cao et al., 2012). We used Smart PLS 3.0 software to run PLS-SEM. Hair et al. (2011) point out that PLS-SEM deals efficiently with a variety of problems with fewer identification issues when the range of the sample size is wide. In our study, PLS-SEM is a suitable method, because it analyzes the data with a more robust prediction that fulfills the objective of our study. We performed the outer model evaluation through the PLS-SEM algorithm for the reliability and validity assessment of the measures. For the inner model evaluation, we performed bootstrapping procedure (5000 subsamples) for testing the research hypotheses.

\subsection{Measures}

In order to carry out our study, we distributed around 1600 questionnaires in total, sending nearly 1400 online and 200 offline for our convenience, and received $264(19 \%)$ and $144(72 \%)$ response rate respectively. We took impulsive buying from (Ridgway et al., 2008), and analyzed it by using three-item questionnaire (Lo and Harvey, 2011). For measuring hedonic shopping motivations, measures were taken for gratification seeking (GRA), role shopping (ROL), adventure seeking (ADV), social shopping (SOC), idea shopping (IDE), and value shopping (VAL) from the study of (Arnold and Reynolds, 2003). A five-point Likert scale was used to measure all variables: 1 representing strongly disagree and 5 representing strongly agree. Sociodemographic questions about age, gender, education, and income were included in the questionnaire. First, the questionnaire was developed in 
English, and then it was translated and back-translated into Chinese by two different professional Chinese persons to ensure the content validity.

\subsection{Missing Values, Composite Reliability, and Validity}

In our study, the values of composite reliability for all the constructs are found to be greater than the standard value 0.7 which is universally acceptable as a minimum applicable criterion for reliability (Fornell and Larcker, 1981). Composite reliability, which is known as Dillon-Goldstein's rho, and Cronbach's Alpha whose values in our study are found to be above 0.7 for all the indicators except adventure seeking value which is found to be minute below the acceptable threshold of 0.60 . Since, standard required value of composite reliability meets for all the constructs, we include 'adventure seeking' value in the analysis. Moreover, Cronbach's Alpha and composite reliability values are considered at 0.60 as the lowest acceptable threshold and average variance extracted values are greater than 0.50 as shown in Table \# 3 (Bagozzi and Yi, 1988). Hence, it validates the construct reliability and convergent validity. There is none found as a missing value, so it is free from any potential bias that could alter the results. Meeting the VIF (variance inflation factor) criteria which are a measure that makes sure that there is no multicollinearity in the model studied. Fulfilling all the basic requirements for conducting the study, it paves the way for the data to be processed for further analysis (Hair Jr et al., 2016).

\section{Research Model/Conceptual Framework}

Following the roadmap of underlying research assumptions, it comes next to assess the structural model (Li et al., 2018) in which reliability is found to be 0.34 . The value of $\mathrm{R}$ square brings more confidence in our research findings with a predictive accuracy at a significance value lying up to 0.05 . All of the variable items in the model are found to be significant and above the required criteria of 0.708 (Hair Jr et al., 2016).

\section{Results and Discussion}

Since the pace of China's markets and consumer living conditions have been tremendously improving, it underscores to study hedonic shopping motivations of young Chinese consumers with the six dimensions namely: role shopping, adventure seeking, gratification seeking, idea shopping, social shopping, and value shopping. Chinese consumers are found to be high rollers (Zeng and Forrest, 2009). They do not believe shopping as a mere transaction but pleasure, discovery, and adventure. Additionally, they are found to take great interest in adventure seeking, gratification seeking, and idea shopping that contribute to impulsive buying, whereas role shopping is found to be inversely related to impulsive buying. Surprisingly, social shopping and value shopping are found to be insignificant to impulsive buying.

Adventure seeking is found to be significant to impulsive buying confirming the previous study on emerging markets (Horváth and Adigüzel, 2017). Hence, we confirm the hypothesis H1. It also confirms the findings that impulsive buying tendencies show a strong correlation with adventure seeking (Khare, 2012). The adventure such as sought in attractive ambiance, facilitating layout, and the entertainment enhance the consumers' visits to the retailers and their impulsive shopping thereby as well (Babin et al., 1994, Jones, 1999). Adventure in shopping may not be a direct goal for consumers, but it is perceived as an emotional state that satisfies indirectly their hedonic needs.

Gratification seeking is found to be an important factor for consumers' significant effect on their motivation towards impulsive shopping (Novak et al., 2000). Hence, the hypothesis H2 is confirmed. It supports the findings in one of the previous studies which were experimented by playing a song with lyrics that generated more impulsive buying motivation online compared to showing motionless images (Adelaar et al., 2003). Gratification helps improve consumers' mood by stimulating their sense of pleasure while shopping and as a result, it enhances their impulsive buying.

Idea shopping is found to be positively contributing to impulsive buying, as a marketplace is an exchange center replete with new ideas and innovations in a real setting. It attracts more consumers to visit the hyper store even at distance (Davis and Hodges, 2012). Hence, we confirm the hypothesis H3. It supports the findings that human needs information and external guidelines to know about himself or herself. It directs us to believe that some consumers window shop in order to enjoy the contact with the fashion world and learn more about new ideas, products, and services.

Role shopping is found to be exceptionally negatively significant to impulsive buying at $10 \%$ significance value against our suggested hypothesis H4. According to the authors' understanding, young Chinese impulsive buyers are not inclined to buy for others even though they obsessively shop for themselves excessively. One of the reasons could be, as gift giving and shopping for others have different meanings in different cultures. China as an emerging country holds the findings of (Green and Alden, 2010) wherein emerging economies, shopping for others is considered more as a utilitarian in nature than hedonic. Hence, we reject the hypothesis H4.

Social shopping is found to be insignificant to impulsive buying. This implies that Chinese impulsive buyers tend not to believe social shopping as a motivating hedonic factor for their impulsive buying. Hence, we 
reject the hypothesis H5. Though our findings are contrary to the results of earlier studies. Falode et al. (2016) where highly pleasant in-store social environments enhance impulsive buying (Mattila and Wirtz, 2008), yet it suggests a number of valuable marketing implications such as; marketers should not spend a lot of marketing budget on advertising their products on social events for Chinese impulsive buyers are found to shop regardless of bonding with family, friends or dear ones. They do not intend to socialize with others while shopping, as they are found to believe that shopping is not a social occasion.

Value shopping is found to be negatively insignificant to impulsive buying. It indicates that Chinese consumers, especially young generation aged around 24 tend not to consider discounts, sales or bargains as a hedonism driving factor for their impulsive shopping. According to our understanding, Chinese consumers are undergoing a major change in their taste of life as their living standard is improving at a fast pace. Therefore, discounts, sales, and bargains are less likely to affect their motivation to buy things impulsively. On the other hand, discounts, sales, and bargains hurt the sense of quality and are found to reduce the motivation of impulsive buyers who shop for hedonic purposes. Hence, we reject the hypothesis H6.

\section{Implications}

This study suggests fundamental customer insights for business firms. Creatively designing the retail layout, innovative product assortment, and displaying product variety and information will help business firms a great deal to attract this consumer segment. On the other hand, recommending these buyers to buy a gift or keepsake for others could be detrimental to attract such consumers for they are more concerned to satisfy their own shopping urge than look to buy for others.

It behooves marketers at the same time to understand the shortcomings of encouraging impulsive buying regarding gifts, souvenirs, and keepsakes. Business firms may not build a customer base, because impulsive buyers are more prone to switching brands and retailers (Horváth and Birgelen, 2015). Moreover, they accumulate excessive and unmanageable debts (O'Guinn and Faber, 1989) resulting in their refraining from shopping finally and completely.

However, impulsive buyers are susceptible to be attracted at first sight by providing them exciting shopping experiences such as adventure; making them feel like they are in their own world, gratification; providing them a customized environment and control, and ideas; building effective showrooms and showcases to let them see and experience new brands, trends, and fashions. Whereas role shopping having a negative relationship to impulsive buying, salespersons should avoid suggesting and commenting on how such and such products look on these consumers and recommending them for giving a gift to their dear ones.

Impulsive buyers, in the long run, are less likely to be a stable customer base for business organizations. So, marketers should not attempt to exploit the sensitive touchpoints of these susceptible buyers ethically. As previous studies have recognized their adverse consequences (Faber and O'Guinn, 1992). It may bring them down financially and often result in stress (Horváth et al., 2015).

\section{Limitations and Future Study}

This study is novel for many insights but it is not nevertheless free from limitations. Our study is based on mostly Chinese female respondents comprising 76 percent of the total respondents. So, it would be quite interesting to carry out a comparative study on males and females for evaluating their differences and similarities of their behaviors on the current topic.

Gender has been a major factor in understanding shopping motivations. Men are more prone to convenience seeking and information seeking, while women are more prone to web browsing and assortment seeking for uniqueness (Noble et al., 2006). However, it could also be studied across various countries with moderating effect of culture.

With the limited study on online hedonic shopping motivations, it calls for the in-depth study on learning what hedonic factors motivate impulsive buyers to shop online. Moreover, the differences between impulsive buying and compulsive buying can further be investigated with respect to hedonic shopping motivations. This area of research has been quite vacuous and invite a deep study further.

\section{References}

ADELAAR, T., CHANG, S., LANCENDORFER, K. M., LEE, B. \& MORIMOTO, M. 2003. Effects of media formats on emotions and impulse buying intent. Journal of Information Technology, 18, 247-266.

ANDERSON, K. C., KNIGHT, D. K., POOKULANGARA, S. \& JOSIAM, B. 2014. Influence of hedonic and utilitarian motivations on retailer loyalty and purchase intention: a facebook perspective. Journal of Retailing and Consumer Services, 21, 773-779.

ARNOLD, M. J. \& REYNOLDS, K. E. 2003. Hedonic shopping motivations. Journal of Retailing, 79, 77-95.

BABIN, B. J., DARDEN, W. R. \& GRIFFIN, M. 1994. Work and/or fun: measuring hedonic and utilitarian shopping value. Journal of consumer research, 20, 644-656. 
BAGOZZI, R. P. \& YI, Y. 1988. On the evaluation of structural equation models. Journal of the academy of marketing science, 16, 74-94.

BATRA, R. \& AHTOLA, O. T. 1991. Measuring the hedonic and utilitarian sources of consumer attitudes. Marketing letters, 2, 159-170.

BAUMEISTER, R. F. 2002. Yielding to temptation:Self-control failure,impulsive purchasing,and consumer behavior. Journal of Consumer Research, 28, 670-676.

CAO, X. J., XU, Z. \& DOUMA, F. 2012. The interactions between e-shopping and traditional in-store shopping: an application of structural equations model. Transportation, 39, 957-974.

CHRIS BIGGS, A. C. E. M., PIERRE MERCIER; ANGELA WANG, LINDA ZOU 2017. What China Reveals About the Future of Shopping.

DAVIS, L. \& HODGES, N. 2012. Consumer shopping value: An investigation of shopping trip value, in-store shopping value and retail format. Journal of Retailing \& Consumer Services, 19, 229-239.

DAWSON, S. \& KIM, M. 2009. External and internal trigger cues of impulse buying online. Direct Marketing: An International Journal, 3, 20-34.

DAYAN, J., BERNARD, A., OLLIAC, B., MAILHES, A. S. \& KERMARREC, S. 2010. Adolescent brain development, risk-taking and vulnerability to addiction. Journal of Physiology - Paris, 104, 279-286.

EVANSCHITZKY, H., EMRICH, O., SANGTANI, V., ACKFELDT, A. L., REYNOLDS, K. E. \& ARNOLD, M. J. 2014. Hedonic shopping motivations in collectivistic and individualistic consumer cultures. International Journal of Research in Marketing, 31, 335-338.

FABER, R. J. \& O'GUINN, T. C. 1992. Clinical Screener for Compulsive Buying | Journal of Consumer Research | Oxford Academic. Journal of Consumer Research, 19, 459-469.

FALODE, B. O., AMUBODE, A. A., ADEGUNWA, M. O. \& OGUNDUYILE, S. R. 2016. Online and Offline Shopping Motivation of Apparel Consumers in Ibadan Metropolis, Nigeria. International Journal of Marketing Studies, 8, 150.

FORNELL, C. \& LARCKER, D. F. 1981. Evaluating structural equation models with unobservable variables and measurement error. Journal of marketing research, 39-50.

GAN, C. 2017. Understanding WeChat users' liking behavior: An empirical study in China. Computers in Human Behavior, 68, 30-39.

GEORGE, B. 2002. The relationship between lottery ticket and scratch - card buying behaviour, personality and other compulsive behaviours. Journal of Consumer Behaviour: An International Research Review, 2, 7-22.

GREEN, R. T. \& ALDEN, D. L. 2010. Functional equivalence in cross-cultural consumer behavior: Gift giving in Japan and the United States. Psychology \& Marketing, 5, 155-168.

GÜLTEKIN, B. \& ÖZER, L. 2012. The Influence of Hedonic Motives and Browsing On Impulse Buying. Journal of Economics \& Behavioral Studies.

HAIR, J. F., RINGLE, C. M. \& SARSTEDT, M. 2011. Journal of Marketing Theory and Practice: From the special issue guest editors. Journal of Marketing Theory \& Practice, 19, 135-137.

HAIR JR, J. F., HULT, G. T. M., RINGLE, C. \& SARSTEDT, M. 2016. A primer on partial least squares structural equation modeling (PLS-SEM), Sage Publications.

HARMANCIOGLU, N., ZACHARY FINNEY, R. \& JOSEPH, M. 2009. Impulse purchases of new products: an empirical analysis. Journal of Product \& Brand Management, 18, 27-37.

HERABADI, A. G., VERPLANKEN, B. \& VAN KNIPPENBERG, A. 2010. Consumption experience of impulse buying in Indonesia: Emotional arousal and hedonistic considerations. Asian Journal of Social Psychology, 12, 20-31.

HIRSCHMAN, E. C. \& HOLBROOK, M. B. 1982. Hedonic Consumption: Emerging Concepts, Methods and Propositions. Journal of Marketing, 46, 92-101.

HOCH, S. J. \& LOEWENSTEIN, G. F. 1991. Time-Inconsistent Preferences and Consumer Self-Control. Journal of Consumer Research, 17, $492-507$.

HORVÁTH, C. \& ADiGÜZEL, F. 2017. Shopping enjoyment to the extreme: Hedonic shopping motivations and compulsive buying in developed and emerging markets. Journal of Business Research.

HORVÁTH, C. \& BIRGELEN, M. V. 2015. The role of brands in the behavior and purchase decisions of compulsive versus noncompulsive buyers. European Journal of Marketing, 49, 2-21.

HORVÁTH, C., BÜTTNER, O. B., BELEI, N. \& AD1GÜZEL, F. 2015. Balancing the balance: Self-control mechanisms and compulsive buying. Journal of Economic Psychology, 49, 120-132.

HOU, J. \& ELLIOTT, K. 2016. Gender differences in online auctions. Electronic Commerce Research and Applications, 17, 123-133.

IYER, E. S. 1989. Unplanned Purchasing: Knowledge of shopping environment and. Journal of retailing, 65, 40.

JACK, S. \& RONAN, K. R. 1998. Sensation seeking among high-and low-risk sports participants. Personality and Individual differences, 25, 1063-1083.

JONES, M. A. 1999. Entertaining shopping experiences: an exploratory investigation. Journal of retailing and 
consumer services, 6, 129-139.

JONES, M. A., REYNOLDS, K. E., WEUN, S. \& BEATTY, S. E. 2003. The product-specific nature of impulse buying tendency. Journal of business research, 56, 505-511.

KACEN, J. J. \& LEE, J. A. 2002. The Influence of Culture on Consumer Impulsive Buying Behavior. Journal of Consumer Psychology, 12, 163-176.

KHARE, A. 2012. Impact of consumer decision-making styles on Indian consumers' mall shopping behaviour. International Journal of Indian Culture and Business Management, 5, 259-279.

KUKAR-KINNEY, M., RIDGWAY, N. M. \& MONROE, K. B. 2012. The Role of Price in the Behavior and Purchase Decisions of Compulsive Buyers. Journal of Retailing, 88, 63-71.

KUKAR-KINNEY, M., SCHEINBAUM, A. C. \& SCHAEFERS, T. 2016. Compulsive buying in online daily deal settings: An investigation of motivations and contextual elements. Journal of Business Research, 69, 691-699.

LEE, J. A. \& KACEN, J. J. 2008. Cultural influences on consumer satisfaction with impulse and planned purchase decisions. Journal of Business Research, 61, 265-272.

LI, W., BHUTTO, T. A., NASIRI, A. R., SHAIKH, H. A. \& SAMO, F. A. 2018. Organizational innovation: the role of leadership and organizational culture. International Journal of Public Leadership, 14, 33-47.

LO, H.-Y. \& HARVEY, N. 2011. Shopping without pain: Compulsive buying and the effects of credit card availability in Europe and the Far East. Journal of Economic Psychology, 32, 79-92.

LUO, X. 2005. How does shopping with others influence impulsive purchasing? Journal of Consumer psychology, 15, 288-294.

MANGLEBURG, T. F., DONEY, P. M. \& BRISTOL, T. 2004. Shopping with friends and teens' susceptibility to peer influence. Journal of retailing, 80, 101-116.

MATTILA, A. S. \& WIRTZ, J. 2008. The role of store environmental stimulation and social factors on impulse purchasing. Journal of Services Marketing, 22, 562-567.

MCDANIEL, S. R. \& ZUCKERMAN, M. 2003. The relationship of impulsive sensation seeking and gender to interest and participation in gambling activities. Personality and Individual differences, 35, 1385-1400.

NGAI, J. \& CHO, E. 2012. The young luxury consumers in China. Young Consumers, 13, 255-266.

NOBLE, S. M., GRIFFITH, D. A. \& ADJEI, M. T. 2006. Drivers of local merchant loyalty: Understanding the influence of gender and shopping motives. Journal of Retailing, 82, 177-188.

NOVAK, T. P., HOFFMAN, D. L. \& YUNG, Y.-F. 2000. Measuring the customer experience in online environments: A structural modeling approach. Marketing science, 19, $22-42$.

O'GUINN, T. C. \& FABER, R. J. 1989. Compulsive buying: A phenomenological exploration. Journal of consumer research, 16, 147-157.

OTNES, C. \& MCGRATH, M. A. 2001. Perceptions and realities of male shopping behavior. Journal of retailing, 77, 111-137.

PETTIGREW, S., BIAGIONI, N., JONES, S. C., DAUBE, M., KIRBY, G., STAFFORD, J. \& CHIKRITZHS, T. 2015. Sales promotion strategies and youth drinking in Australia. Social Science \& Medicine, 141, 115-122.

RAYBURN, S. W. \& VOSS, K. E. 2013. A model of consumer's retail atmosphere perceptions. Journal of Retailing and Consumer Services, 20, 400-407.

RIDGWAY, N. M., KUKAR-KINNEY, M. \& MONROE, K. B. 2008. An expanded conceptualization and a new measure of compulsive buying. Journal of Consumer Research, 35, 622-639.

ROOK, D. W. 1987. The buying impulse. Journal of consumer research, 14, 189-199.

ROOK, D. W. \& FISHER, R. J. 1995. Normative Influences on Impulsive Buying Behavior | Journal of Consumer Research | Oxford Academic. Journal of Consumer Research, 22, 305-313.

ROOK, D. W. \& GARDNER, M. P. 1993. In the mood: Impulse buying's affective antecedents. Research in Consumer Behavior, 6, 1-28.

ROOK, D. W. \& HOCH, S. J. 1985. Consuming impulses. Advances in Consumer Research, 12, 23-27.

SHARMA, P., SIVAKUMARAN, B. \& MARSHALL, R. 2010. Impulse buying and variety seeking: A traitcorrelates perspective. Journal of Business Research, 63, 276-283.

STONE, G. P. 1954. City shoppers and urban identification: observations on the social psychology of city life. American Journal of Sociology, 60, 36-45.

TAUBER, E. M. 1972. Why do people shop? The Journal of Marketing, 46-49.

TIFFERET, S. \& HERSTEIN, R. 2012. Gender differences in brand commitment, impulse buying, and hedonic consumption. Journal of Product \& Brand Management, 21, 176-182.

TO, P.-L., LIAO, C. \& LIN, T.-H. 2007a. Shopping motivations on Internet: A study based on utilitarian and hedonic value. Technovation, 27, 774-787.

TO, P. L., LIAO, C. \& LIN, T. H. 2007b. Shopping motivations on Internet: A study based on utilitarian and hedonic value. Technovation, 27, 774-787.

VERPLANKEN, B. \& HERABADI, A. 2001. Individual differences in impulse buying tendency: feeling and no 
thinking. European Journal of Personality, 15, S71-S83.

XU, Y. \& HUANG, J.-S. 2014. Effects of price discounts and bonus packs on online impulse buying. Social Behavior and Personality: an international journal, 42, 1293-1302.

YOUN, S. \& FABER, R. J. 2000. Impulse buying: its relation to personality traits and cues. ACR North American Advances.

YU, C. \& BASTIN, M. 2010. Hedonic shopping value and impulse buying behavior in transitional economies: A symbiosis in the Mainland China marketplace. Journal of Brand Management, 18, 105-114.

ZENG, Z. L. \& FORREST, D. 2009. High rollers from Mainland China: a profile based on 99 cases. Unlv Gaming Research \& Review Journal, 29-43.

ZHANG, J. W., HOWELL, R. T. \& HOWELL, C. J. 2016. Living in wealthy neighborhoods increases material desires and maladaptive consumption. Journal of Consumer Culture, 16.

ZHENG, X., LIU, N. \& ZHAO, L. A Study of the Effectiveness of Online Scarce Promotion--Based on the Comparison of Planned Buying and Unplanned Buyingi. the twelfth wuhan international conference on ebusiness, 2013.

ZIMMERMAN, I. 2012. What motivates impulse buying. Psychology Today. Retrieved from https://www. psychologytoday. com/blog/sold/201207/what-motivates-impulse-buying.

ZUCKERMAN, M. 1993. Sensation seeking and impulsivity: A marriage of traits made in biology. The impulsive client: Theory, research, and treatment, 71-91.

\section{Figure 1 Impulsive Buyers}

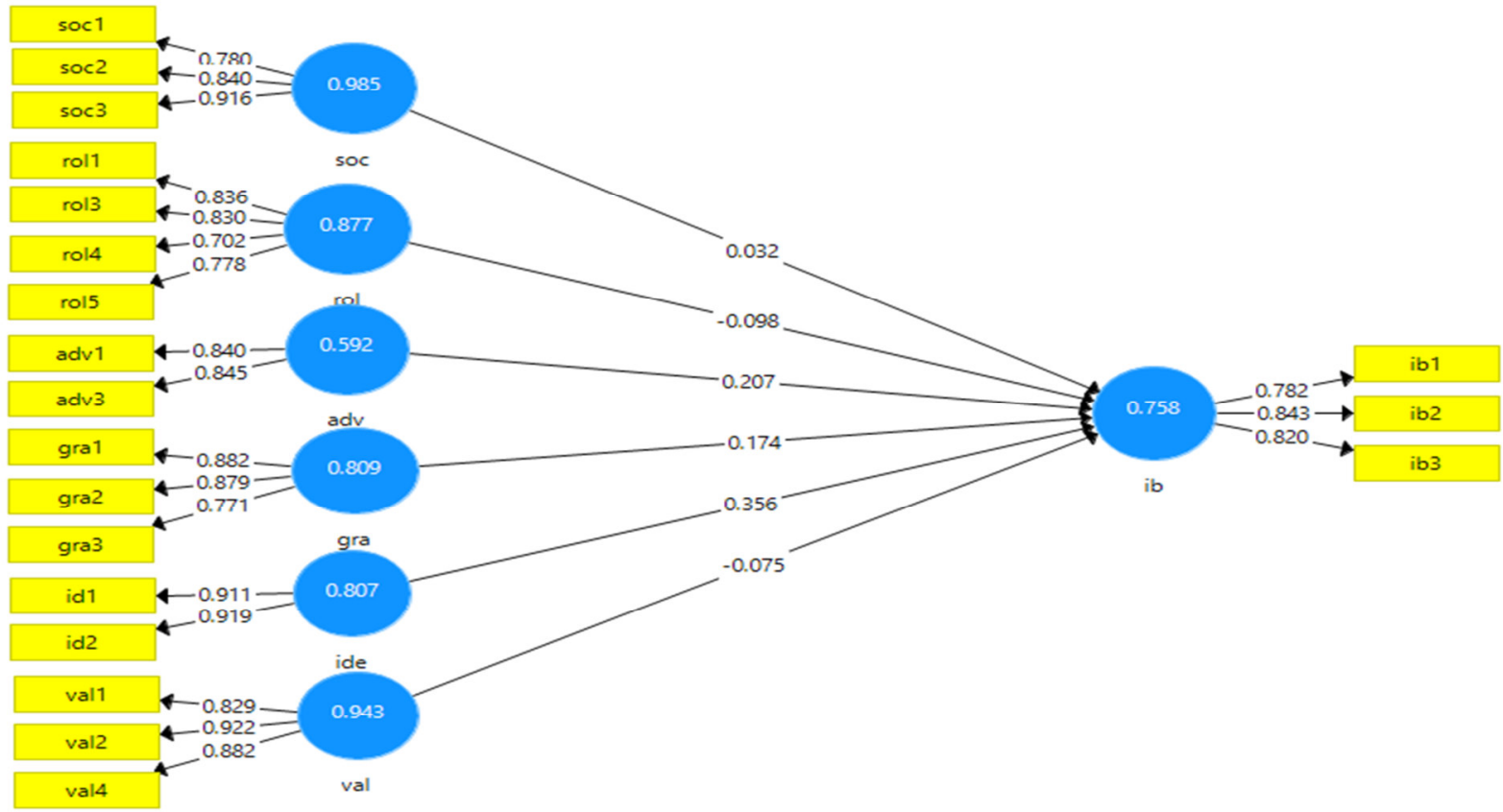

$\mathrm{ROL}=$ role shopping, $\mathrm{ADV}=$ adventure seeking, $\mathrm{SOC}=$ social shopping, $\mathrm{GRA}=$ gratification seeking, IDE=idea shopping, $\mathrm{VAL}=$ value shopping, $\mathrm{IB}=$ impulse buying 
Table 1. Demographic Profile of Respondents

\begin{tabular}{cccc}
\hline Demographic variable & Category & Frequency & Percent \\
\hline Gender & Male & 147 & 24 \\
& Female & 468 & 76 \\
Age & Below 18 & 11 & 2 \\
& $18-22$ & 402 & 65 \\
Education & $23-27$ & 135 & 22 \\
& Above 27 & 67 & 11 \\
& Bachelors & 456 & 74 \\
Income/month (RMB) & Masters & 108 & 18 \\
& PhD & 20 & 3 \\
& Other & 31 & 5 \\
& Below 3000 & 466 & 76 \\
& $3000-6000$ & 96 & 16 \\
\hline
\end{tabular}

\begin{tabular}{cc} 
Table 2. R Square and R Square Adjusted Values \\
\hline R Square & R Square Adjusted
\end{tabular}

Impulsive buyers

0.34
0.33

Table 3. Indicators' Reliability, Rho, Composite Reliability, and AVE Values

\begin{tabular}{ccccc}
\hline & Cronbach's Alpha & $\mid$ Rho_A & Composite Reliability & $\begin{array}{c}\text { Average Variance } \\
\text { Extracted (AVE) }\end{array}$ \\
\hline ADVENTURE & 0.592 & 0.592 & 0.831 & 0.710 \\
GRATIFICATION & 0.799 & 0.809 & 0.882 & 0.715 \\
IB & 0.750 & 0.758 & 0.856 & 0.665 \\
IDEA & 0.806 & 0.807 & 0.912 & 0.837 \\
ROLE & 0.825 & 0.877 & 0.867 & 0.622 \\
SOCIAL & 0.819 & 0.985 & 0.884 & 0.718 \\
VALUE & 0.859 & 0.943 & 0.910 & 0.772 \\
\hline
\end{tabular}

Table 4. Path Coefficient, Significance, and VIF Values

\begin{tabular}{cccc}
\hline Constructs & P.C Value & Sig: Val & VIF Val \\
\hline ADV & 0.207 & 0.000 & 2.344 \\
GRA & 0.174 & 0.001 & 2.398 \\
IDE & 0.356 & 0.000 & 1.452 \\
ROL & -0.098 & 0.092 & 2.128 \\
SOC & 0.032 & 0.543 & 2.234 \\
VAL & -0.075 & 0.128 & 1.732 \\
\hline
\end{tabular}

Table 5. Discriminant Validity

\begin{tabular}{|c|c|c|c|c|c|c|c|}
\hline & adventure & & gratification & $\mathrm{ib}$ & idea & role & social \\
\hline adventure & 0.843 & & & & & & \\
\hline gratification & 0.728 & 0.845 & & & & & \\
\hline $\mathrm{ib}$ & 0.467 & 0.445 & 0.815 & & & & \\
\hline idea & 0.524 & 0.496 & 0.511 & 0.915 & & & \\
\hline role & 0.430 & 0.453 & 0.162 & 0.321 & 0.789 & & \\
\hline social & 0.409 & 0.471 & 0.175 & 0.247 & 0.675 & 0.847 & \\
\hline value & 0.322 & 0.353 & 0.092 & 0.215 & 0.579 & 0.608 & 0.879 \\
\hline
\end{tabular}


Table 6. Hypotheses Assessment

\begin{tabular}{llllll}
\hline & Hypothesized path & b-value & t-value & p-value & decision \\
\hline H1 & adventure -> ib & 0.207 & 6.115 & 0.000 & Supported \\
H2 & gratification - $>$ ib & 0.174 & 2.462 & 0.001 & Supported \\
H3 & idea -> ib & 0.356 & 5.479 & 0.000 & Supported \\
H4 & role - ib & -0.098 & 1.478 & 0.092 & Rejected \\
H5 & social -> ib & 0.032 & 0.283 & 0.543 & Rejected \\
H6 & value -> ib & -0.075 & 1.552 & 0.128 & Rejected \\
\hline
\end{tabular}

$\mathrm{ib}=$ impulsive buying

Table 7. Factor Analysis of Consumer Characteristics

\begin{tabular}{|c|c|c|c|c|}
\hline Constructs & $\begin{array}{l}\text { Composite } \\
\text { Reliability }\end{array}$ & Items & Estimate & t-value \\
\hline \multirow[t]{2}{*}{ Adventure seeking } & $\begin{array}{l}0.831 \\
(\mathrm{a}=0.59)\end{array}$ & I find shopping stimulating & 0.840 & 38.224 \\
\hline & & To me, shopping is an adventure & 0.845 & 36.855 \\
\hline \multirow[t]{3}{*}{ Gratification seeking } & $\begin{array}{l}0.882 \\
(\mathrm{a}=0.80)\end{array}$ & $\begin{array}{l}\text { When I am in bad mood, I go shopping to make } \\
\text { me feel better }\end{array}$ & 0.882 & 63.921 \\
\hline & & To me shopping is a way to relieve stress & 0.879 & 68.980 \\
\hline & & $\begin{array}{l}\text { I go shopping when I want to treat myself to } \\
\text { something special }\end{array}$ & 0.771 & 30.392 \\
\hline \multirow[t]{3}{*}{ Impulsive buying } & $\begin{array}{l}0.856 \\
(\mathrm{a}=0.75)\end{array}$ & I buy things I did not plan to buy & 0.782 & 33.434 \\
\hline & & I buy things I do not need & 0.843 & 49.828 \\
\hline & & I consider myself as an impulse purchaser & 0.820 & 45.263 \\
\hline \multirow[t]{2}{*}{ Idea shopping } & $\begin{array}{l}0.912 \\
(\mathrm{a}=0.81)\end{array}$ & I go shopping to keep up with the trends & 0.911 & 70.784 \\
\hline & & I go shopping to keep up with the new fashions & 0.919 & 92.788 \\
\hline \multirow[t]{4}{*}{ Role shopping } & $\begin{array}{l}0.867 \\
(a=0.83)\end{array}$ & $\begin{array}{l}\text { I like shopping for others because they feel good } \\
\text { I feel good }\end{array}$ & 0.836 & 11.569 \\
\hline & & I enjoy shopping for my friends and family & 0.830 & 8.475 \\
\hline & & $\begin{array}{l}\text { I feel good when I buy things for the special } \\
\text { people in my life }\end{array}$ & 0.702 & 5.024 \\
\hline & & $\begin{array}{l}\text { I enjoy shopping around to find the perfect gift } \\
\text { for someone }\end{array}$ & 0.778 & 7.675 \\
\hline \multirow[t]{3}{*}{ Social shopping } & $\begin{array}{l}0.884 \\
(\mathrm{a}=0.82)\end{array}$ & $\begin{array}{l}\text { I go shopping with my friends or family to } \\
\text { socialize }\end{array}$ & 0.780 & 10.905 \\
\hline & & Shopping with others is a bonding experience & 0.840 & 15.009 \\
\hline & & $\begin{array}{l}\text { To me, shopping with friends or family is a } \\
\text { social occasion }\end{array}$ & 0.916 & 32.634 \\
\hline \multirow[t]{3}{*}{ Value shopping } & $\begin{array}{l}0.910 \\
(\mathrm{a}=0.86)\end{array}$ & $\begin{array}{l}\text { For the most part, I go shopping when there are } \\
\text { sales }\end{array}$ & 0.829 & 4.573 \\
\hline & & I enjoy looking for discounts when I shop & 0.922 & 7.357 \\
\hline & & I go shopping to take advantage of sales & 0.882 & 6.583 \\
\hline
\end{tabular}

